\title{
Assessing the Construct and Convergent Validity of Trait Meta-mood Scale among Suez Canal university Students during Corona Pandemic
}

BY

Dr. Mahmoud Ali Moussa*

\section{Introduction:}

Trait Meta-mood characterizes an individual emotionally and describes the individual's activity as a result of his touch with social and personal experiences for more than two weeks. This state occurs either through behavioral impersonation, or empathy or as a result of being in emotional labor conditions. The anxiety state, the lack of bias, and the depression symptoms be affected in meta-mood condition.

Meta-mood can be measuring emotional intelligence state. An individual can show social desirability in expressing his emotional mentality considering the response on the Likert scale. Meta-mood is like emotional contagion, but in prolonged social and emotional circumstances. There is a difference between the features of meta-mood and emotional contagion. Emotional contagion refers to positive and negative emotional influence, which leads to mood modification in the event of positive repetition or mood disturbance towards stress stimuli. While Meta- moods express emotional control and emotional attention to the individual responses, the ability to correct emotions, clarity of feelings and their appropriateness in relation to the current situation, and this suitability are either due to the current circumstances or because of an emergency event that affected the individual's expectations

Emotional intelligence is the description and evaluation of socially enough behavior. It is also seen as the ability to know and understand one's emotions and feelings. As well as those of other individuals. It is associated with the clinical aspects studying some psychological features such as Alexithymia, which led to the individual's inability to express, understand and expose his emotions either verbally or gesticulations and mimes done (Fiori \& Vesely-Maillefer, 2018).

* Lecturer of Educational Psychology, Educational Psychology department, Faculty of Education, Suez Canal university 
There are two approaches to studying emotional intelligence: the trait and the ability approach. It is as follows:

$>$ First, the trait approach: This refers to the emotional intelligence as behavioral biases such as personality traits or selfbeliefs. Mayer \& Salovey $(1993,2007)$ states it is a mix of traits, competencies, and abilities.

$>$ Second, the ability Approach according to Mayer \& Salovey (1997) which is a cognitive ability that cares about emotionally processing information and evaluating the performance of sentiments.

The students' reluctance to persist through activities is the reason why we used the trait meta-mood scale. Because of the stressful mood that university students are going through. students' fear of expressing their emotions and exposing them in. the researcher mentioned that instrument is a unique approach to classify the emotional intelligence of his students.

Nearly all countries have paid attention to reduce the consequences of the Corona disease. In universities students failed to attend college without ever warning that bad mood. The semester is limited to a period of three months, and the period of the end of the COVID-19 is unknown.

The more time passes, students suffer from Mood dysfunction. The student mental health was influenced by their fear of disease infection. The announced policies to complete the study are also unfamiliar to students. These policies led to psychological conflicts. Psychological and academic stress was reflected in the emotional state. As a result of the learner's permanent stay at home, students are not venting for his emotions. Thus, assessing emotional intelligence with familiar measurements became impossible.

\section{The association between emotion and mood:}

Emotion is defined as one of three or four basic categories of mental processes. These categories include motivation, passion, awareness and mood (Mayer \& Salovey, 1993). The main impulses arise in response to the internal physical state and include some stimuli such as hunger, thirst, the need for social contact and sexual desires. Motives are responsible for directing an organism to do simple actions in order to meet survival and reproductive needs. Therefore, the motives have a specific time path, that is, they are temporary, and they make the individual satisfied until this motive is satiated and turns off (Mayer, Roberts, \& Barsade, 2008). 
Emotion develops in the context of relationships between stimuli and responses by changing relationships between the individual and his environment. For example, anger arises as a response to the threat of injustice and aggression. Fear arises in response to sensed risk. Emotions respond to observed changes in relationships. Fear leads to behavioral reactions, either complaining or escaping. Thus, emotions are further flexible than motivations and less flexible than perception (Lin, Gosnell \& Gable, 2019; Mayer, Salovey \& Caruso, 2008; Mayer et al., 2008).

Perception allows a person to learn from the experience going through emotions during the new problem-solving that did not pass in advance and did not have previous emotional experience. Perception serves motivation to maintain positive emotions as the individual realizes the responses that provoke others, and uses it to improve emotion of the other to enable him to agree with him on the long term, that is, cognition is the focus of the emotional processing of emotional experience (Ferrer, Klein, Avishai, Jones, Villegas \& Sheeran, 2018; Lin et al., 2019; Mayer \& Salovey, 1993; Mayer, Salovey, Caruso \& Sitarenios, 2001, 2003).

The mood is the intersecting processes of awareness, perception, and emotion. For example, a person is aware of the emotional response that will stimulate and arouse the other side that the individual to preserve the general mood of it. That is, the mood is a long-term process, but not sustainable because it influenced by individual differences. The mood is an accompanying process that excites an individual when he feels pleasure due to his success in meeting the motivation and awareness of the emotional experience with all its emotions.

\section{Trait Meta-Mood Scale (TMMS)}

Salovey, Mayer, Goldman, Turvey \& Palfai (1995) used traits metamood is a measure of emotional intelligence that is perceived in terms of an individual's beliefs in emotional intelligence. That is, a measure to assess an individual's beliefs about his emotional ability. It is a trait that deals with three main elements of emotional intelligence (FernándezBerrocal, Extremera \& Ramos, 2004): (1) drawing attention to the extent to which an individual tends to adopt his feelings and Moods and think about them. (2) feelings clarity and a meaningful understanding of the emotional and emotional states of one. (3) Mood Repair refers to an individual's beliefs and his ability to organize his feelings.

Emotional intelligence is the ability to think and manage sensations, impressions and emotions (Salovey, Stroud, Woolery \& Epel, 2002). 
Mayer \& Gaschke (1988) assumed that individuals are continually thinking about their feelings. mood experience may be measured by the trait meta-mood scale. It was developed by Salovey et al. (1995) a 3 subscales measure: emotional attention, feeling clarity, and mood repair.

Emotional attention refers to the perceived ability to recognize its own emotions. It measures how well people imagination they notice their feelings. Feelings clarity indicates the perceived ability to discriminate between negative and positive feelings. It is just how much people think they understand their mood (Martín-Albo, Núñtez \& León, 2010). Mood repair refers to the perceived ability to regulate mood. Ability to regulate mood and fix negative emotional experiences.

The previous studies (Aradilla-Herrero, Tomás-Sábado \& Gómez-Benito, 2014; Del-Carmen-Giménez-Espert \& Prado-Gascó, 2017; Gómez-Núñez, Torregrosa, Inglés, Lagos San Martín, Sanmartín, Vicent \& García-Fernández, 2020; Valdivia Vazquez, Rubio Sosa \& French, 2015) used CFA modeling to verify the construct validity. They proved that the three factors, first order CFA for adults. Factorial stability used to test the same factor loading in order to the same factors as (Aradilla-Herrero et al., 2014; Del-Carmen-Giménez-Espert \& Prado-Gascó, 2017) tested.Rockhill \& Greener (1999) revealed that the general factor models. But Brito-Costa, Castro, Moisao, Alberty, de Almeida \& Fernández (2016) explored the six factors, first order EFA model. The median of Cronbach's alpha reliability was .83 for adolescents and adults.

\section{Method:}

4.1.Design: Descriptive approach used to verify factor structure of trait meta-mood scale among the study participants.

4.2.Participants: Corona pandemic has spread in Egypt in March 2020, data was collected from freshmen in Suez Canal University using an online platform (https://forms.gle/3cSEZuBy7AzQ8mrS7).Participants were informed about the confidentiality of their responses, and informed that participation was strictly volunteering 214 volunteer students participated (dividing by gender as $9.8 \%$ males, $\mathbf{9 0 . 2 \%}$ females). the same participants were drawn from $15 \%$ were in College of Arts and Humanities, and $85 \%$ from College of Education.

4.3.Measures:

Trait meta-mood scale: A24-item scale adapted to Spanish from the original version developed by Del-Carmen-Giménez-Espert \& Prado- 
Gascó, (2017) was used. It measures the degree of understanding of mood and attention to reactions given by emitting individual, and an evaluation of emotions and perception by others of the emotions issued by the individual. And repairing the mood in the path of the current situation to adapt to the social context. The scale uses a 5-point Likert response format $(1=$ never, $2=$ rarely, $3=$ sometimes, $4=$ often, and $5=$ always). Eight (8) items refer to emotional attention (e.g 'I usually care a lot of how I feel'), and 8 items refer to feeling clarity (e.g. 'I can describe the feelings rounded in my mind') and 8 items refer to mood repair (e.g. 'I have more strength when I feel happy').

Emotional contagion scale: $(\mathrm{M}=46.16, \mathrm{SD}=\mathbf{8 . 3 5})$, a 15 -item scale adapted by Doherty (1997). It measures the degree of individuals' emotional stimulation that occurs during the context with emotional responses and withdrawals. Agreement with items are on 5-point Likert scale $(1=$ never, $2=$ rarely, $3=$ sometimes, $4=$ often, $5=$ always $)$. The Cronbach's alpha reliability was $\mathbf{7 4}$ for the current data.

4.4.Procedures and Data analysis:

Responses on sub-scales were done by Lisrel 8.50 and IBM SPSS V.20 statistics for windows. Confirmatory factor analysis (CFA) was used to examine the suitability of the scale to the Egyptian society. We evaluated the data fit of first order CFA. The item factor loadings below .40 were eliminated. The accepted goodness of fit indices in the paper were: RMSEA $\leq .50$; NNFI $\geq .95$; GFI $\geq .95$; SRMR implies to zero (Pai et al., 2006). External validity performed on the scale with emotional contagion scale. Descriptive statistics and metric have been computed to sub-scales.

5. Results and discussion:

5.1.Content validity: The items were presented to a language specialist to verify the accuracy of the translation. The researcher also presented the translated scale to a group of colleagues in the field of Educational Psychology and Mental Health to verify the item suitability. Some contexts for items 1, 5, $17,21,23$ and 24 were improved, so that the statements are appropriate, and do not have ambiguity and confusion on the part of the reader who responds to items.

5.2. Construct validity: the three factors, first order CFA model were tested. The goodness-of-fit indices showed a reasonable fit GFI $=.90, \mathrm{NNFI}=.90$, and $\mathrm{RMSEA}=.045$. The analysis performed by Lisrel was 8.50. The internal consistency structures obtained through correlation matrix are presented in Table 1. 
Table 1: internal consistency of trait meta-mood sub-scales.

\begin{tabular}{llll}
\hline Sub-scale & $($ EA) & (EA) & (EA) \\
\hline Emotional attention (EA) & $\mathbf{1 . 0 0}$ & & \\
\hline \multirow{3}{*}{ Feeling clarity (FC) } & .27 & & \\
& $(.07)$ & 1.00 & \\
Mood repair (MR) & 3.79 & & \\
& -.16 & .40 & \\
& $(.07)$ & $\mathbf{( . 0 7 )}$ & 1.00 \\
\hline
\end{tabular}

Notes: $\mathrm{EA}=$ emotional attention, $\mathrm{FC}=$ feeling clarity, $\mathrm{MR}=\operatorname{mood}$ repair, $\mathrm{n}=\mathbf{2 1 4}$

According to table 1, there are statistically low and medium correlation coefficients, which means that the three factors are not satisfied with the $2^{\text {nd }}$ order overall factor. table. 2 . present factorial structure loadings of trait meta-mood sub-scales items. The items and factor loadings are given in Table 2.

Table 2: Factor loading of meta-mood subscales.

\begin{tabular}{|c|c|c|c|c|c|}
\hline Factor & No. & Items & $\begin{array}{l}\text { Factor } \\
\text { loading }\end{array}$ & $\begin{array}{l}\text { Std } \\
\text { error }\end{array}$ & $\begin{array}{l}\text { t- } \\
\text { value }\end{array}$ \\
\hline \multirow{8}{*}{$\begin{array}{l}\text { Emotional } \\
\text { attention }\end{array}$} & 1 & I pay more awareness to feelings & .60 & .063 & 9.46 \\
\hline & 2 & I usually care a lot of how I feel & .53 & .064 & 8.18 \\
\hline & 3 & $\begin{array}{l}\text { I usually waste time thinking my } \\
\text { sentiments }\end{array}$ & .66 & .061 & 10.78 \\
\hline & 4 & $\begin{array}{l}\text { I think deserve to have attention to } \\
\text { my feelings and } \operatorname{mood}\end{array}$ & .55 & .064 & 8.61 \\
\hline & 5 & My feelings affect my thoughts & .68 & .061 & 11.19 \\
\hline & 6 & $\begin{array}{l}\text { I continue thinking of my state of } \\
\text { mind }\end{array}$ & .31 & .068 & 4.59 \\
\hline & 7 & I often think touching my feelings & .84 & .056 & 15.02 \\
\hline & 8 & I pay attention to how I feel & .57 & .063 & 9 \\
\hline \multirow{8}{*}{$\begin{array}{l}\text { Feelings } \\
\text { Clarity }\end{array}$} & 9 & I am clear on my feelings & .45 & .067 & 6.78 \\
\hline & 10 & I can often determine my feelings & .65 & .063 & 10.39 \\
\hline & 11 & $\begin{array}{l}\text { My feelings and actions are } \\
\text { appropriate }\end{array}$ & .65 & .062 & 10.48 \\
\hline & 12 & $\begin{array}{l}\text { My specific feelings are correct } \\
\text { towards people }\end{array}$ & .43 & .067 & 6.32 \\
\hline & 13 & $\begin{array}{l}\text { I often notice my feelings in } \\
\text { varying situations }\end{array}$ & .30 & .069 & 4.28 \\
\hline & 14 & $\begin{array}{l}\text { I can describe the feelings } \\
\text { rounding in my mind }\end{array}$ & .44 & .067 & 6.65 \\
\hline & 15 & $\begin{array}{l}\text { Sometimes I can know what my } \\
\text { feelings are }\end{array}$ & .68 & .062 & 10.93 \\
\hline & 16 & I can understand my emotions & .80 & .059 & 13.71 \\
\hline $\begin{array}{l}\text { Mood } \\
\text { repair }\end{array}$ & 17 & $\begin{array}{l}\text { I have an optimistic thought, no } \\
\text { matter how anxious I feel }\end{array}$ & .68 & .062 & 11.06 \\
\hline
\end{tabular}




\begin{tabular}{|l|l|l|l|l}
18 & $\begin{array}{l}\text { Even if I feel wrong, I try to think } \\
\text { like beautiful things }\end{array}$ & .83 & .057 & 14.47 \\
\hline 19 & $\begin{array}{l}\text { When I feel depressed, I think of } \\
\text { all life pleasures }\end{array}$ & .55 & .064 & 8.57 \\
\hline 20 & $\begin{array}{l}\text { I try to have positive opinions even } \\
\text { if I feel bad }\end{array}$ & .87 & .056 & 15.49 \\
\hline 21 & $\begin{array}{l}\text { I am looking for calming me down } \\
\text { if everything gets complicated }\end{array}$ & .65 & .061 & 10.72 \\
\hline 22 & $\begin{array}{l}\text { I was afraid of becoming a good } \\
\text { mood }\end{array}$ & -.035 & .069 &.- .51 \\
\hline 23 & $\begin{array}{l}\text { I have more strength when I feel } \\
\text { happy }\end{array}$ & .20 & .069 & 2.96 \\
\hline 24 & $\begin{array}{l}\text { When I am angry, I try to change } \\
\text { my mood in the front of others }\end{array}$ & .21 & .068 & 3.07 \\
\hline
\end{tabular}

The first 8-items were loading to 'emotional attention', items 9 to 16 were related to 'feeling clarity', item (22) was omitted for 'mood repair'. The scale factor loading ranged -.035 to .87 .

The CFA model was fitted to the Suez Canal university students' participants. The CFA fitted to the Egyptian society.

\subsection{Reliability:}

Cronbach's alpha reliability for sub-scales ranged from .80 and .87 as Del-Carmen-Giménez-Espert \& Prado-Gascó (2017) computed. The scale was stable with a Cronbach's alpha of $\mathbf{. 8 0}$. Alpha coefficient was .81 for emotional attention and alpha if item deleted ranged from .81 and .82 and item-6 was deleted. Alpha coefficient was .78 for feeling clarity and alpha if item deleted ranged from .72 and .79. Alpha coefficient was $\mathbf{7 8}$ for mood repair and alpha if item deleted ranged from .70 and .81 and item-24 was deleted.

The alpha reliability was $\mathbf{. 8 0}$. It is lower than the median of the previous studies ' 0.83 '. that is an indicator of the lower the scores of meta-moods and emotional states for Suez Canal University students.

5.4. Convergent validity:

Recent prior studies (Bhullar, 2012; Kuang, Peng, Xie \& Hu, 2019) have confirmed the existence of correlations between emotional contagion and mood. The more positive contagion, the better the individual's mood, then the more badly contagion by negative emotions affected badly on mood state. that can be depending on the assessment of the role of emotions prevalent in the current social context.

convergent validity depends on the Pearson correlation calculation between the emotional contagion total score and trait meta-mood subscales scores and presented in Table 3 .

Table 3: Pearson relationships for trait meta-mood sub-scales. 


\begin{tabular}{lllllll}
\hline & \multicolumn{2}{c}{ Emotional attention } & \multicolumn{2}{c}{ Feelings clarity } & \multicolumn{2}{c}{ Mood repair } \\
\cline { 2 - 7 } & $\mathrm{r}$ & $\boldsymbol{P}$-value & $\mathrm{r}$ & $\boldsymbol{P}$-value & $\mathrm{r}$ & $\boldsymbol{P}$-value \\
\hline $\begin{array}{l}\text { Emotional } \\
\text { contagion }\end{array}$ & .13 & .053 & .14 & .049 & .003 & .962 \\
\hline
\end{tabular}

Table 3. shows that the emotional contagion isn't correlated with emotional attention $(r=.13, P>.05)$, the results showed no correlation with Mood repair $(r=.003, P=.962)$, even that there was a statistically significant correlation between contagion and feeling clarity $(r=.14, P$ $=.049)$. those correlations confirmed the convergent validity.

Since, emotional arousal leads to nervousness, the individual moods appear in states of anger, anxiety and fear. This assumption confirms the positive correlation between feelings clarity and emotional contagion.

5.5.Metrics of trait meta-mood scale:

Initially, descriptive statistics indices for the three sub-scales are presented in Table 4.

Table 4: Descriptive statistics of trait meta-mood sub-scales.

\begin{tabular}{lllll}
\hline & \multicolumn{4}{c}{ Descriptive statistics } \\
\cline { 2 - 6 } Sub-scale & Mean & Std & skewness & Kurtosis \\
\hline Emotional attention & 27.49 & 4.98 & -.63 & .09 \\
\hline Feeling clarity & 29.18 & 4.92 & -.26 & .33 \\
\hline Mood repair & 21.83 & 5.10 & -.36 & .35 \\
\hline The results showed that sub-scales have semi-normal (Skewed) & sat \\
distribution according to the students' scores. Percentiles went to \\
describe meta-mood states as a guide or indicator of emotional \\
intelligence as presented in table 5.
\end{tabular}

Table 5: Percentiles for trait meta-mood sub-scales.

\begin{tabular}{llll}
\hline \multirow{2}{*}{ Percentiles } & \multicolumn{2}{l}{ Trait meta-mood sub-scale } & \\
\cline { 2 - 4 } & Emotional attention & Feeling clarity & Mood repair \\
\hline $\mathbf{1 0} \%$ & 21 & 22 & 15 \\
\hline $25 \%$ & 23 & 25 & 18 \\
\hline $30 \%$ & 24 & 26 & 18 \\
\hline $40 \%$ & 25 & 27 & 19 \\
\hline $50 \%$ & 27 & 29 & 20 \\
\hline $60 \%$ & 28 & 30 & 22 \\
\hline $70 \%$ & 30 & 31 & 24 \\
\hline $75 \%$ & 31 & 32 & 25 \\
\hline $80 \%$ & 31 & 33 & 26 \\
\hline $90 \%$ & 32 & 33 & 29 \\
\hline
\end{tabular}


A lower degree in subscale than $25 \%$ means that the individual needs to behavioral intervention to modify his emotions. Any researcher may need cut-off scores for one or more dimensions as a basic sample for his research. In the field of education and psychology, the researcher needs to control emotional variables (e.g. especially emotional attention) influencing cognitive processing in working memory.

Finally, this study had some limitations. First, the inability to generalize the results to the practical colleges of the university, such as science and tourism ... etc. Second, the sample on which the results are tested is small for the sample community of the two colleges $(1,400$ students for education, 1,700 faculty of arts and humanities). Finally, the participants represent 19 departments for the College of Education and only one department of 11 in the College of Arts and Humanities.

6. Conclusion:

This paper introduced the Arabic version of TMMS-24 items in Egyptian society. It has good alternative instrument suitability to test the emotional intelligence. Researchers in educational psychology areas can be used it as alternative instrument to test the emotional aspects.

This instrument measures EI as a general ability represented by emotional attention, mood repair, and feeling clarity. Consequently, the researcher argues that this instrument can focus EI in its past, actual and futuristics states.

The emotional states and mood traits of the Suez Canal university student were badly influenced due to Pandemic of corona virus. Poorly influenced as indicated by the measure's parameter (GFI, and NNFI = 0.90).

Conflict of interest: The author declares that he does not have any other relations with organizations, trade associations, companies, unions, (including civic associations and public interest groups) that may gain or lose financially from the results or conclusions in the study.

Ethical Approval: All procedures performed in this study involving human participants according to the ethical standards of the University's Research Ethics Board. Participants had previous known of the paper objectives. 


\section{References}

Aradilla-Herrero, A., Tomás-Sábado, J., \& Gómez-Benito, J. (2014). Perceived emotional intelligence in nursing: psychometric properties of the $T$ rait $M$ eta-M ood S cale. Journal of Clinical Nursing, 23(78), 955-966.

Bhullar, N. (2012). Relationship between $\operatorname{mood}$ and susceptibility to emotional contagion: is positive mood more contagious?. North American Journal of Psychology, 14(3), 517-529.

Brito-Costa, S., Castro, F. V., Moisao, A., Alberty, A., de Almeida, H., \& Fernández, M. I. R. (2016). Psychometric properties of Portuguese version of trait meta-mood scale (TMMS24). Revista INFAD de Psicología. International Journal of Developmental and Educational Psychology., 2(1), 133-142.

Carranza-Lira, S., MacGregor-Gooch, A. L., \& SarachagaOsterwalder, M. (2004). Mood modifications with raloxifene and continuous combined estrogen plus progestin hormone therapy. International Journal of Fertility and Women's Medicine, 49(3), 120-122.

Del-Carmen-Giménez-Espert, M., \& Prado-Gascó, V. J. (2017). Emotional intelligence in nurses: The Trait Meta-Mood Scale. Acta Paulista de Enfermagem, 30(2), 204.

Fernández-Berrocal, P., Extremera, N., \& Ramos, N. (2004). Validity and reliability of the Spanish modified version of the Trait MetaMood Scale. Psychological Reports, 94(3), 751-755.

Fiori, M., \& Vesely-Maillefer, A. K. (2018). Emotional intelligence as an ability: theory, challenges, and new directions. In Emotional intelligence in education (pp. 23-47). Springer, Cham.

Gómez-Núñez, M. I., Torregrosa, M. S., Inglés, C. J., Lagos San Martín, N. G., Sanmartín, R., Vicent, M., \& García-Fernández, J. M. (2020). Factor Invariance of the Trait Meta-Mood Scale-24 in a Sample of Chilean Adolescents. Journal of Personality Assessment, 102(2), 231-237.

Pai, A. L. H., Mullins, L. L., Drotar, D., Burant, C., Wagner, J., \& Chaney, J. M. (2006). Exploratory and confirmatory factor analysis of the child uncertainty in illness scale among children with chronic illness. Journal of Pediatric Psychology, 32(3), 288-296.

Kuang, B., Peng, S., Xie, X., \& Hu, P. (2019). Universality vs. Cultural Specificity in the Relations Among Emotional Contagion, Emotion Regulation, and Mood State: An Emotion Process Perspective. Frontiers in psychology, 10(186), 1- 11. 
Martín-Albo, J., Núñtez, J. L., \& León, J. (2010). Analysis of the psychometric properties of the Spanish version of the Trait MetaMood Scale in a sports context. Psychological Reports, 106(2), 477489.

Mayer, J. D., \& Gaschke, Y. N. (1988). The experience and metaexperience of mood.Journal of Personality and Social Psychology, 55(1), 102- 111.

Mayer, J. D., \& Salovey, P. (1993). The intelligence of emotional intelligence. Intelligence, 17, 433- 442.

Mayer, J. D., \& Salovey, P. (1997). What is emotional intelligence? In P. Salovey \& D. J. Sluyter (Eds.), Emotional development and emotional intelligence: Educational implications (pp. 3-34). New York, NY: Basic Books.

Mayer, J. D., \& Salovey, P. (2007). Mayer-Salovery-Caruso emotional intelligence test. Toronto: Multi-Health Systems Incorporated.

Mayer, J. D., Roberts, R. D., \& Barsade, S. G. (2008). Human abilities: Emotional intelligence. Annu. Rev. Psychol., 59, 507-536.

Mayer, J. D., Salovey, P., \& Caruso, D. R. (2008). Emotional intelligence: New ability or eclectic traits?. American Psychologist, 63(6), 503- 517.

Mayer, J. D., Salovey, P., Caruso, D. R., \& Sitarenios, G. (2001). Emotional intelligence as a standard intelligence. Emotion, 1(3), 232242.

Mayer, J. D., Salovey, P., Caruso, D. R., \& Sitarenios, G. (2003). Measuring emotional intelligence with the MSCEIT V2. 0. Emotion, 3(1), 97- 105.

Reinecke, L. (2017). Mood management theory. The international Encyclopedia of Media Effects, 1-13.

Rockhill, C. M., \& Greener, S. H. (1999). Development of the Trait Meta-Mood Scale for Elementary School Children. ERIC database, Champaign, IL.

Salovey, P., Mayer, J. D., Goldman, S. L., Turvey, C., \& Palfai, T. P. (1995). Emotional attention, clarity, and repair: Exploring emotional intelligence using the Trait Meta-Mood Scale. In J. W. Pennebaker (Ed.), Emotion, disclosure, \& health (p. 125-154). American Psychological Association. https://doi.org/10.1037/10182-006

Salovey, P., Stroud, L. R., Woolery, A., \& Epel, E. S. (2002). Perceived emotional intelligence, stress reactivity, and symptom reports: Further explorations using the trait meta-mood scale. Psychology and Health, 17(5), 611-627. 
Valdivia Vazquez, J. A., Rubio Sosa, J. C. A., \& French, B. F. (2015). Examination of the Spanish Trait Meta-Mood Scale-24 Factor Structure in a Mexican Setting. Journal of Psychoeducational Assessment, 33(5), 473-482.

Zillmann, D. (1988). Mood management: Using entertainment to full advantage. In L. Donohew, H. E. Sypher, \& E. T. Higgins (Eds.), Communication, social cognition, and affect (pp. 147-171). Hillsdale, NJ: Lawrence Erlbaum Associates.

Lin, W. F., Gosnell, C. L., \& Gable, S. L. (2019). Goals, emotions, and the effort to be responsive during couple interactions. Motivation and Emotion, 43(2), 313-324.

Ferrer, R. A., Klein, W. M., Avishai, A., Jones, K., Villegas, M., \& Sheeran, P. (2018). When does risk perception predict protection motivation for health threats? A person-by-situation analysis. PloS one, 13(3). 
Assessing the Construct and Convergent Validity of Trait

Meta-mood Scale among Suez Canal university Students during Corona Pandemic

\author{
Dr. Mahmoud Ali Moussa \\ Lecturer of Educational Psychology, Educational Psychology \\ department, Faculty of Education, Suez Canal university
}

\begin{abstract}
:
The paper uses a new alternative instrument for measuring emotional intelligence for a sector from the Egyptian society. The researcher translated the Spanish version into Arabic. The previous studies test the external validity by depression symptoms as a clinical approach. The main objective of this paper is to test construct validity and test the change of meta-mood by influences of Corona virus contagion fear by computed correlations coefficients with the emotional contagion scale. Available sample has been responded. It is consisted of two-hundred and fourteen volunteer students (divided by gender as $9.8 \%$ males and $\mathbf{9 0 . 2 \%}$ females). For the students in the sample, $15 \%$ were in College of Arts and Humanities and $85 \%$ were in College of Education in Ismailia. A confirmatory factor analysis (CFA)results revealed an accepted construct validity in the trait meta-mood scale (GFI $=.90$, NNFI $=.90$, and $\operatorname{RMSEA}=.045)$, the categories were internally consistent $\left(\alpha_{E A}=.81\right.$, $\left.\alpha_{\mathrm{FC}}=.78, \alpha_{\mathrm{MR}}=.78\right)$.
\end{abstract}

Keywords: Emotional intelligence; trait meta-mood; Corona virus, COVID-19. 
تقييم الصدق البنائي والتقاربي لمقياس سمات ما وراء المزاج لاى طلاب جامعة قناة السويس في ظل جائحة كورونا

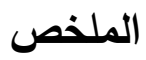

يهاف البحث الحالي إلى التحقق من الصدق البنائي لمقياس سمات ما وراء المزاج، واختبار

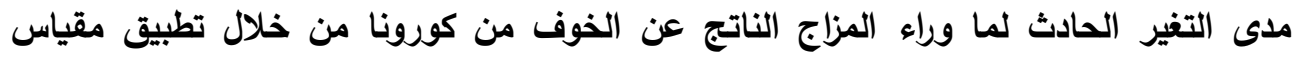

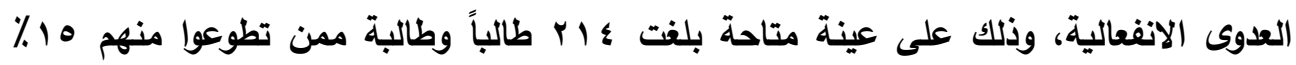

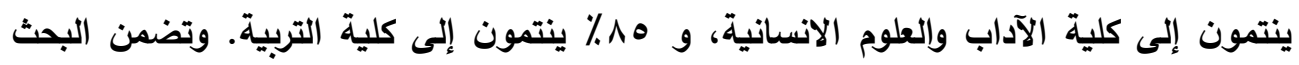

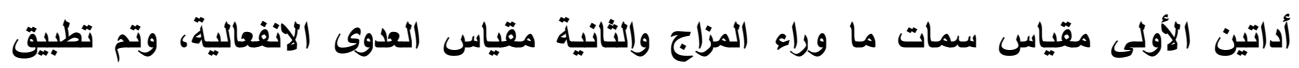

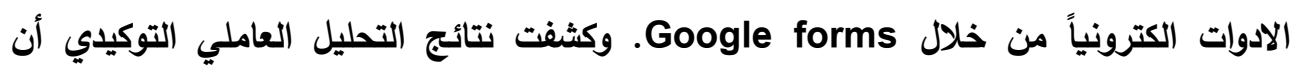

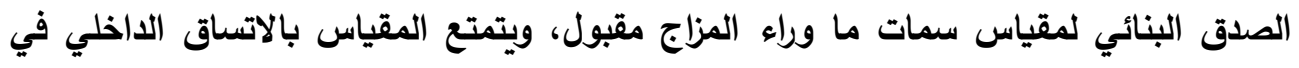
ضوء معاملات ألفا كرونباخ لكل بعد.

الكلمات المفتاحية: الذكاء الوجداني، سمات ما وراء المزاج، فيروس كورونا، كوفيد - 19. 